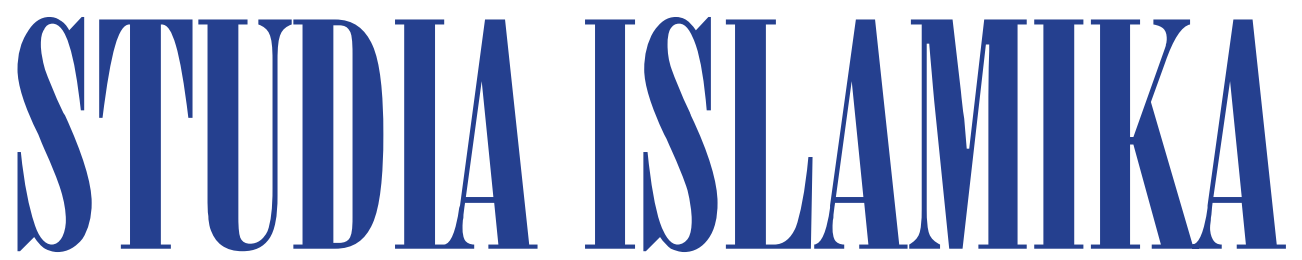

INDONESIAN JOURNAL FOR ISLAMIC STUDIES

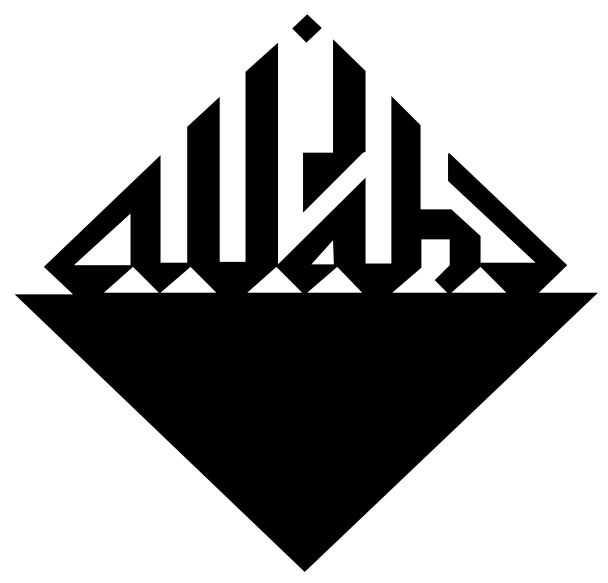

Ritual, BiD'́Ah, ANd the Negotiation of the Public Sphere in Contemporary Indonesia Jajang Jahroni

Historicizing Islam: On the Agency of

Siti Maryam in the Construction of

Bima's HisTORY OF ISLAMIZATION

Muhammad Adlin Sila

Cross-cultural Differences Experienced

during Haju: A Case Study of Acehnese Hajj

Kamaruzzaman Bustamam-Ahmad \& Rahmi Zakaria

Zakat and Poverty Alleviation in a Secular State:

The Case of Muslim Minorities in the Philippines

Alizaman D. Gamon \& Mariam Saidona Tagoranao 
STIUDLA ISLAMIIIKA 



\section{STIDIIA ISLAMIIKK}

Indonesian Journal for Islamic Studies

Vol. 25, no. 1, 2018

EDITOR-IN-CHIEF

Azyumardi Azra

MANAGING EDITOR

Oman Fathurahman

\section{EDITORS}

Saiful Mujani

Jamhari

Didin Syafruddin

Jajat Burhanudin

Fuad Jabali

Ali Munhanif

Saiful Umam

Ismatu Ropi

Dadi Darmadi

Jajang Jahroni

Din Wahid

Euis Nurlaelawati

INTERNATIONAL EDITORIAL BOARD

M. Quraish Shihab (Syarif Hidayatullah State Islamic University of Jakarta, INDONESIA)

Taufik Abdullah (Indonesian Institute of Sciences (LIPI), INDONESIA)

M.C. Ricklefs (Australian National University, AUSTRALIA)

Martin van Bruinessen (Utrecht University, NETHERLANDS)

John R. Bowen (Washington University, USA)

M. Kamal Hasan (International Islamic University, MALAYSIA)

Virginia M. Hooker (Australian National University, AUSTRALIA)

Edwin P. Wieringa (Universität zu Köln, GERMANY)

Robert W. Hefner (Boston University, USA)

Rémy Madinier (Centre national de la recherche scientifique (CNRS), FRANCE)

R. Michael Feener (National University of Singapore, SINGAPORE)

Michael F. Laffan (Princeton University, USA)

\section{ASSISTANT TO THE EDITORS}

Testriono

Muhammad Nida' Fadlan

Endi Aulia Garadian

ENGLISH LANGUAGE ADVISOR

Benjamin J. Freeman

Daniel Peterson

Batool Moussa

ARABIC LANGUAGE ADVISOR

Ahmadi Usman

COVER DESIGNER

S. Prinka 
STUDIA ISLAMIKA (ISSN 0215-0492; E-ISSN: 2355-6145) is an international journal published by the Center for the Study of Islam and Society (PPIM) Syarif Hidayatullah State Islamic University of Jakarta, INDONESIA. It specializes in Indonesian Islamic studies in particular, and Southeast Asian Islamic studies in general, and is intended to communicate original researches and current issues on the subject. This journal warmly welcomes contributions from scholars of related disciplines. All submitted papers are subject to double-blind review process.

STUDIA ISLAMIKA has been accredited by The Ministry of Education and Culture, Republic of Indonesia as an academic journal (SK Dirjen Dikti No. 56/DIKTI/Kep/2012).

STUDIA ISLAMIKA has become a CrossRef Member since year 2014. Therefore, all articles published by STUDIA ISLAMIKA will have unique Digital Object Identifier (DOI) number.

STUDIA ISLAMIKA is indexed in Scopus since 30 May 2015.

Editorial Office:

STUDIA ISLAMIKA, Gedung Pusat Pengkajian

Islam dan Masyarakat (PPIM) UIN Jakarta,

Jl. Kertamukti No. 5, Pisangan Barat, Cirendeu,

Ciputat 15419, Jakarta, Indonesia.

Phone: (62-21) 7423543, 7499272, Fax: (62-21) 7408633;

E-mail: studia.islamika@uinjkt.ac.id

Website: http://journal.uinjkt.ac.id/index.php/studia-islamika

Annual subscription rates from outside Indonesia, institution: US\$ 75,00 and the cost of a single copy is US\$25,00; individual: US\$ 50,00 and the cost of a single copy is US\$ 20,00. Rates do not include international postage and handling.

Please make all payment through bank transfer to: PPIM, Bank Mandiri KCP Tangerang Graha Karnos, Indonesia, account No. 101-00-0514550-1 (USD),

Swift Code: bmriidja

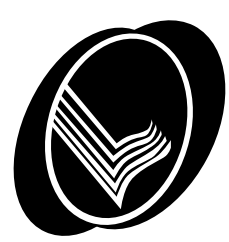

Harga berlangganan di Indonesia untuk satu tahun, lembaga: Rp. 150.000,-, harga satu edisi Rp. 50.000,-; individu: Rp. 100.000,-, harga satu edisi Rp. 40.000,-. Harga belum termasuk ongkos kirim.

Pembayaran melalui PPIM, Bank Mandiri KCP Tangerang Graha Karnos, No. Rek: 128-00-0105080-3 


\section{Table of Contents}

\section{Articles}

$1 \quad$ Jajang Jahroni

Ritual, Bid'ah, and the Negotiation of

the Public Sphere in Contemporary Indonesia

$37 \quad$ Muhammad Adlin Sila

Historicizing Islam: On the Agency of

Siti Maryam in the Construction of

Bima's History of Islamization

67 Kamaruzzaman Bustamam-Ahmad \& Rahmi Zakaria

Cross-cultural Differences Experienced

during Hajj: A Case Study of Acehnese Hajj

97 Alizaman D. Gamon \& Mariam Saidona Tagoranao

Zakat and Poverty Alleviation in a Secular State:

The Case of Muslim Minorities in the Philippines

135 Hermansyah

Khalfiyat wa taḥaddīyāt al-aqalīyah

al-muslimah al-Ṣinīyah fi Pontianak 


\section{Book Review}

177 Dadi Darmadi

Rindu Kembali Ke Baitullah:

Sejarah Haji Asia Tenggara

\section{Document}

199 Dita Kirana

Enhancing Religious Education: An Attempt

to Counter Violent Extremism in Indonesia 
Muhammad Adlin Sila

\title{
Historicizing Islam: On the Agency of Siti Maryam in the Construction of Bima's History of Islamization
}

\begin{abstract}
This article focuses on the understanding of Bima's local interlocutors in the history of Islamization in the region, particularly in light of their construction of Bima vernacular manuscripts. This article provides the agency of Siti Maryam as the owner and caretaker of Samparaja museum who has given access to Bima's manuscripts, locally called Bo'. Through in-depth interviews and participant observation, I examined how Siti Maryam as the manuscript's owner constructs the entry of Islam to Bima, and how this understanding becomes the dominant storyline in explaining Bima's history raging from the pre-Islamic era to the period of Islamization. The aim of this article is not to discuss the truth or falsity in these historical accounts or to take sides. But all these varying historical accounts are important in providing a doorway into understanding the locally dynamic and religio-political practices of Islam in contemporary Bima.
\end{abstract}

Keywords: Siti Maryam, History, Islam, Islamization, Bima. 
Abstrak: Artikel ini fokus pada pemahaman dari subjek penelitian tentang sejarah Islam di Bima, yang secara khusus terkait pada pemahaman mereka tentang naskah-naskah lokal. Artikel ini menyediakan pemahaman Siti Maryam sebagai pemilik dan penjaga Museum Samparaja yang telah memberikan akses terhadap manuskrip Bima yang dalam bahasa lokal disebut Bo'. Melalui wawancara-wawancara mendalam dan partisipasi terlibat, saya menguji bagaimana Siti Maryam sebagai pemilik manuskrip mengkonstruksi masuknya Islam ke Bima dan bagaimana pemahaman ini menjadi cerita dominan dalam menjelaskan sejarah Bima mulai dari masa pra Islam hingga periode Islamisasi Bima. Tujuan dari artikel ini bukan untuk mendiskusikan kebenaran atau kepalsuan catatan-catatan sejarah yang ada atau mendukung salah satu kelompok. Tapi catatancatatan sejarah yang beragam ini penting dalam menyediakan jalan masuk terhadap pemahaman dinamika lokal dan praktek politik Islam di Bima saat ini.

Kata kunci: Siti Maryam, History, Islam, Islamisasi, Bima.

$$
\begin{aligned}
& \text { ملخص: ركزت هذه المقالة على فهم موضو ع البحث حول تاريخ الإسلام في بيما الذي } \\
& \text { يرتبط بصفة خاصة بفهم المخطوطات المحلية. قدمت هذه المقالة فهم سيتي مريم؛ صاحبة } \\
& \text { وحارسة متحف سامبار اجا التي أعطت لي فرصة الاطلاع على مخطوطات بيما التي تطلق } \\
& \text { في اللغة المحلية باسم 》بو 《) (Bo). فمن خلال حوارات عميقة ومشاركات فعالة، قمت } \\
& \text { باختبار طريقة قامت بها سيتي مريم باعتبارها صاحبة المخطوطات في بناء دخول الإسلام }
\end{aligned}
$$

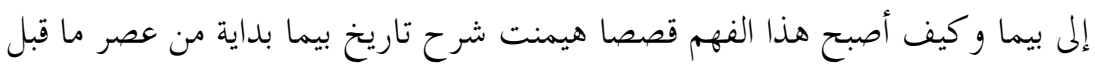

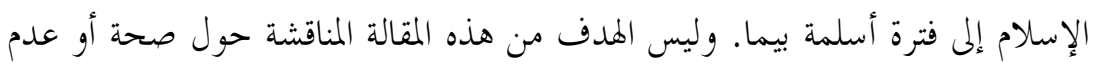

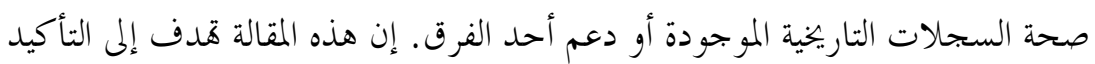

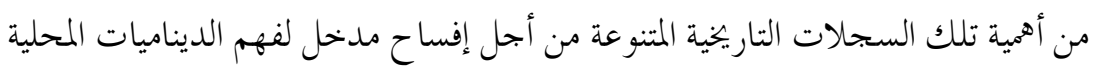

$$
\begin{aligned}
& \text { والممارسات السياسية الإسلامية في بيما في الوقت الراهن. } \\
& \text { الكلمات المفتاحية: سيتي مريم، التاريخ، الإسلام، الأسلمة، بيما. }
\end{aligned}
$$


T $\mathrm{n}$ this anthropological study, I focus on the agency of the local interlocutors in the understanding of the history of Islamization in Bima. A book entitled Bo' Sangaji Kai (2000), written jointly by French philologist Henri Chambert-Loir and Bima philologist Siti Maryam R. Salahuddin, is the transliteration and translation of Bima manuscripts, and has been useful to scholars working on Bima history. I was excited when I managed to visit Siti Maryam in her house in Salama, Rasanae, on the first day of my fieldwork in Bima in August 2011. Siti Maryam was mentioned by many people when I asked who I should consult to understand historical accounts of Bima, particularly on the entry of Islam to Bima. On one of my visits to her home in January 2012, I discussed an article written by Noorduyn (1987b) entitled 'Makassar and the Islamization of Bima', who concluded that the Gowa kingdom defeated and Islamised the Bima kingdom. As a defeated kingdom, Bima was forced to provide tribute and bridegrooms to the Gowa kingdom.

Siti Maryam, or Ruma Mari (she is called by this name as she is the heir of the Bima Sultanate), was already aware of Noorduyn's work and reacted by saying: 'Noorduyn is right in that the Gowa kingdom sent their army to conquer the Bima king. But the defeated king, Salise, was actually the traitor. He had violated our Raja Bicara's oath (i.e., Sumpah Bilmana or the oath of Raja Bicara Bilmana) by assassinating the young prince and taking the throne. Thanks to the Gowa kingdom, the real king was returned to his throne.' So Noorduyn is right in that the Gowa kingdom sent its army to conquer the king of Bima, but the traitor. As I discuss this below, Siti Maryam's critique of Noorduyn's account shows her position in understanding the history of Islam in Bima, in particular how the Bima ruler accepted Islam. She acknowledged her direct descent from the murdered young prince and this conversation alerted me to fact that there were varying understandings of what had happened in the seventeenth century, and that these were relevant to differences I was observing in Islam in Bima today.

To begin with, I provide a profile of Siti Maryam and the way she incorporates local sources in understanding the history of the Islamization of Bima. The following sections will portray how Malay scripts (Ind.: Jawi) became the medium for recording the history of Bima from the pre-Islamic era to the coming of Islam. I will also depict the people of Bima, their political orientations and social stratification, 
family and kinship terms. The concluding section analyses the diverse political motivation that influences the transliteration and translation, as well as the understanding of the history of Bima Islamization.

\section{Siti Maryam and Samparaja Museum}

Siti Maryam is the founder and caretaker of the Samparaja museum, which is a private museum dedicated to local history. It takes its name from Samparaja, the name of the dagger that is part of the Bima regalia. Siti Maryam is referred to locally and addressed as Ruma Mari, which is her noble title. She is a widow of a non-noble police officer who died around the same time she founded the museum. Now in her early eighties, Siti Maryam is well off. She was strong enough to go to Bandung in West Java by plane, and sometimes by a two day road trip to pursue her doctoral studies in philology at Padjadjaran University, which she finished in 2010 at the age of 83 . The focus of her thesis was Bima vernacular literature during the Bima Sultanate. This indicates that she is not only the heir of the Bima Sultanate but also a scholar on Bima, especially in the study of manuscripts. ${ }^{1}$

She once explained to me that the main aim of the Samparaja Museum was to preserve the remnants of the Bima Sultanate, in particular the manuscripts. To borrow her phrase in local language: 'ka bou ma ntoi' or, 'to renew the old.' She is strongly committed to preserving the traditions of the Bima Sultanate, as she understands them and her political position may colour her interpretation of historical documents. Siti Maryam recounted her meeting in 1984 with Prince Bernhard, the husband of Princess Yuliana from the Netherlands, who visited Bima on his way to Komodo island. In that short visit, Prince Bernhard was stunned when he looked at the original manuscripts of Bo' Sangaji Kai. 'If this is the only copy available, you have to preserve it, otherwise you will lose your history,' warned Prince Bernhard. After that meeting, Siti Maryam determined to find the best way to preserve the manuscripts. This motivation led her to found the museum in 1987, which was officially opened by the local district head Adi Haryanto on August 10, 1995. ${ }^{2}$ However, it only holds manuscripts relating to the Sultan, and not the Raja Bicara.

In my visit to Samparaja Museum in December 2011, I found hundreds of pages of Jawi manuscripts dating from the seventeenth to the nineteenth century. ${ }^{3}$ They are known locally as $B o^{\prime}$ (a word possibly 
derived from the word Bo' which means book in Makassarese. ChambertLoir and R. Salahuddin (2000, xii) have written that work on the Jawi manuscript began in the period of Lambila (his posthumous name is Makapiri Solo), the son of Ma Wa' a Bilmana, when he accompanied La $\mathrm{Ka}$ ' $\mathrm{i}$ in his exile in Gowa kingdom and converted to Islam. But only in the period of the second Sultan, Abi'l Khair Sirajauddin (1640-1682), did the Bima Sultan officially announce the use of Jawi as the script for the sultanate. The Sultan said in Malay: 'Dengan memakai bahasa Melayu dengan rupa tulisan yang diridai oleh Allah ta'ala' (with the use of Malay language in the form of writing that is endorsed by God).

The Samparaja museum has collections of Jawi manuscripts stored in three different rooms. The manuscripts contain a variety of scientific and historical records ranging across agricultural and marine sciences, astrology, relationships and interactions with foreign traders, as well as customary laws that have been applied from the pre-Islamic era up to the time of the Bima Sultanate. There is one manuscript that tells the origin of Bima in the fourteenth century. It was written in the period of Sultan Muhammad Ali Syah (1696-1673) which took as its source an old Bima manuscript written in Bima script during the era of king Manggampo Donggo on 13 September 1504 (or 23 Jumadil Awwal $910 \mathrm{H}$ ). Bima originally had its own indigenous script similar to the ancient Makassar script but it has been replaced by Jawi script. The old manuscript was also a rewritten version from the manuscript written in 1333. Most Jawi manuscripts were written from 1756 to 1824 under three Sultans: Abdul Kadim, Abdul Hamid and Ismail, and these became the source of the transliteration and translation of Bo' Sangaji Kai (Chambert-Loir and R. Salahuddin 2000). The manuscript tells in detail the story of the coming of Indra Zamrud, the ancestor of Bima kings.

The museum has preserved the manuscripts by laminating nearly 2,500 sheets, which are expected to last between 50 to 100 years. The National Library in Jakarta has also carried out preservation through digital technology and microfilm and this includes nearly 2,200 old manuscripts. Overall, the manuscripts that have been laminated, digitized, and microfilmed amounted to 4,700 sheets of both loose and bound manuscripts. The museum is also home to old ceramics, old stamps of Bima sultans of the previous period, photos of sultans, pictures of regalia including daggers (Bim.: sampari, Ind.: keris) and 
crowns, royal musical instruments, and the book collection of the royal family.

Chambert-Loir (1985b) had access to a number of these manuscripts and as noted above he published some of them together with Siti Maryam R. Salahuddin in 1999 under the title Bo' Sangaji Kai (the chronicles of Bima's sultan). While this book has made the manuscripts accessible to a wider public, it took me months to obtain permission from Siti Maryam to see and take pictures of the original manuscript of the Bo' Sangaji Kai. My impression is that members of the royal family and former officials of the Bima Sultanate treat these local manuscripts as 'treasure' and they keep them secret from outsiders. ${ }^{4}$ Siti Maryam said:

My dream is to preserve all the manuscripts owned by Bima people. There are a great number of $B o^{\prime}$ that have not been found due to the reluctance of other member of the royal family to give access to their manuscripts. But I will not give up if my age permits. To be honest, I obtained the original copy of the manuscript Bo' Sangaji Kai from someone who has no connection with the royal family. That is very sad. I also found the old copy of the Qur'an written by Syekh Subur, the Imam of the Bima Sultanate, in the era of Sultan Alauddin Muhammad Syah (17311748-) from someone else. But I donated the Qur'an to the Baitul Qur'an in the Ministry of Religious Affairs.

Chambert-Loir and R. Salahuddin (2000) explained that Bo' Sangaji Kai is only one type of the Jawi manuscripts found on Bima. They argued that to fully understand the history of Bima, one must study all types of Bima chronicles (i.e., all types of $B o^{\prime}$ ), as well as other manuscripts (e.g. Makassar manuscripts) and the Dutch archives. Chambert-Loir and R. Salahuddin (2000: xii) found that apart from Bo' Sangaji Kai, there are other types of $B o^{\prime}$, including Bo' Bicara Kai (the manuscripts of Raja Bicara), Bo' Bumi Luma Rasana'e (the manuscript of the top official in the Bima palace), Bo' Kadi (the manuscripts of the head of religious council, Bim.: sara huku), Bo' Melayu (the manuscript of the Malay leader), and Bo' Dae Duru (the manuscript of the Makassar noble in Bima). When Raja Bicara Muhammad Kuraisy died in 1918, the collection of the Bo' Bicara Kai was sent to the palace of Bima Sultan and allegedly destroyed when the palace was accidently burned (Chambert-Loir 2004, 20). Fortunately, two of those manuscripts still exist, namely the Bo'Sangaji Kai and the Bo'Bumi Luma Rasana'e. The last manuscript was recently published in 2010 in Indonesian entitled Iman dan Diplomasi: Serpihan Sejarah Kerajaan Bima. ${ }^{5}$ 
Jawi manuscripts (or $B o$ ) which came to being in the seventeenth century, the time when Bima was Islamised, record the history of Bima from the pre-Islamic era to the time of Bima Sultanate. Previous scholars including H. Zollinger (1851), Henri Chambert-Loir (1985a, 1985b, 2004), Henri Chambert-Loir and Siti Maryam R. Salahuddin (2000), Peter Just (1989, 2001), J. Noorduyn (1987a, 1987b), Michael Hitchcock (1996) and Michael Prager (2010) have used the Jawi manuscripts to interpret the history and culture of Bima people. The manuscripts enable us to reach back to the beginnings of Islam Bima, and we can use these documents to discuss and incorporate them into an historical account relevant to the present.

My engagement with these previous works are, however, confined to the opinion offered by Robinson and Paeni $(1998,71)$, who argued that as anthropologists, we should not rely only on local manuscripts, as they 'provide only a partial record of past cultural practices.' I therefore use critical approaches to the works of previous scholars, including local scholars, to examine the ways that different scholars write about historical facts in reference to the Jawi manuscripts. This allows me to address the historical construction of Bima people, and enables me to understand the general processes and larger structuring principles that shape contemporary Bima people and how the manuscripts are used in the present.

\section{The Malay and the Bima Chronicles}

The use of Malay script or Jawi to record the historical narratives indicates that the Malay language not only became the medium of communication, or lingua franca, between Bima Sultans and other Sultans, and also with the Dutch. It also became the basis of a Bima literary tradition. Despite the fact that the Makassar Sultanate of Gowa was vital to Bima's Islamization, the Malay influence has been more evident in the literary culture of Bima people than Makassarese. Zollinger $(1851,135)$ and Hitchcock $(1996,43)$ argued that Bima actually had its own script, which resembles Makassar script (Mak.: toa jangang-jangang referring to the ancient Makassarese script). But this Bima script was replaced by Malay script due to the key role of the Malays in compiling the Bima chronicles and in writing Bima's folktales, particularly during the era of the second Bima Sultan. Abi'l Khair Sirajuddin (1640-1682) considered the Makassar script symbolized the pre-Islamic, while the Malay represented the new religion. 
Chambert-Loir published his transliteration of the Jawi manuscripts, entitled Syair Kerajaan Bima (The Poem of Bima Kingdom) (1982) and Ceritera Asal Bangsa Jin dan Segala Dewa-Dewa (The Story of the Origin of Jinns and Gods) (1985a) in 1982 and 1985 respectively. In 2004, Chambert-Loir republished these manuscripts with an additional one entitled Hikayat Sang Bima under the new title Kerajaan Bima dalam Sastra dan Sejarah (The Kingdom of Bima in Literature and History). In this publication, Chambert-Loir $(2004,143)$ notes that the author of the Hikayat Sang Bima is an official of the Bima Sultanate of Malay descent. In the introductory sentence of the Hikayat Sang Bima, the opening statement reads as follows (Chambert-Loir 2004, 151):

Bismillah al-rabman al-rahim. Wa bihi nasta'inu billahi ala. Ini hikayat Sang Bima suatu cerita yang maha indah-indah dan berbagai kesaktian dan gagah beraninya dan memberi heran segala yang mendengar dia.

Syahdan maka adalah seorang-orang Melayu datang ke Bima tatkala zaman Sultan Hasanuddin bernama Dalang Wisa Marta.

In the name of Allah the Merciful and Magnificent. This is the story of Bima, a story of great beauty and enchantment and courage, which stuns everyone who hears it.

There was a Malay who came to Bima in the era of Sultan Hasanuddin and whose name was Dalang Wisa Marta.

The Hikayat Sang Bima and the source of its writing provides a clue to identify local beliefs about the origins of the Bima people that underpin the social hierarchy as it is today (See Lewis 1996, 166). The philological studies of Chambert-Loir (1982, 1985a, 1985b, 2004; 2000), show the adoption of the Malay loan word hikayat, meaning a story, and bismillah, an Islamic opening salutation. This indicates the starting point of the widespread use of Arabic script and Malay language in the area. The availability of the seventeenth century Malay manuscripts evidence the inclusion of Islamic symbols in Bima literature, and the manuscripts are seen to be Islamic (see Cummings $(2001,2010$, 4) for the case of serang script in Makassar).

Apart from studying the works of Chambert-Loir and R. Salahuddin, I also engaged with the works of Abdullah Tajib and Hilir Ismail. Unlike Siti Maryam who has philological expertise, they are historians by training. Abdullah Tajib, a retired history school teacher, wrote the book Sejarah Dana Mbojo (The History of Bima), published by a local Bima publisher in 1999. Hilir Ismail is a graduate from the faculty of history of 
the University of Indonesia and is the founder of the Asi Mbojo Museum located in the former Bima palace. Since its foundation, Asi Mbojo has been under the administration of the Ministry of Culture at the district level where Ismail was working. Thanks to Ismail, the former palace of Bima Sultan was turned into a museum, where he became the head of the museum from 1984 to 1996 . During his tenure, the museum functioned as the place to preserve royal property and artifacts. Hence, he was familiar with the royal artifacts and understood the history of the royal artifacts and regalia in the museum.

The existence of the two museums, Samparaja and Asi Mbojo, is an expression of the contemporary political dynamics relating to the sultanate. Both Siti Maryam and Hilir Ismail are well-known descendants of the royal family of the Bima Sultanate. Although Hilir Ismail was expelled from the nobility due to family issues in the past, ${ }^{6}$ he spent his entire career as a public servant writing a number of books on Bima Sultanate and Bima culture until his untimely passing in January 2011, several months prior to my arrival in Bima. In the aftermath of Hilir Ismail's death, Siti Maryam became the sole speaker of the royal family on Bima history. In the 2012 Hanta U'a Pua festival (the festival commemorating the entry of Islam), Siti Maryam stated during her opening speech that the Asi Mbojo museum was not supposed to be in the former Bima palace and that it must be moved to another location. Nonetheless, many Bima elders I met expressed their gratitude to Hilir Ismail for his role in the provision of books relating to the history and local traditions of the Bima people. Like Siti Maryam, Hilir Ismail bases his works on living traditions as written in the Jawi manuscripts. The difference between these two figures is that Siti Maryam limited herself to the Jawi manuscripts. Meanwhile, Hilir Ismail, as many other historians, did not limit himself to the local manuscripts, but engaged with archaeological materials and artifacts.

In the following section, I will review a number of historical studies on Bima including the works of both Siti Maryam and Hilir Ismail, which describes the condition of Bima people from the era of preIslam to that of the coming of Islam. In this analysis, I engage with the political dimension of contemporary Bima history.

\section{Bima in the Pre-Islamic Era}

Ismail (2004, 15-16 and 23-28) agrees with other scholars such as Just $(1989,2001)$ and Hitchcock (1996) that the first people in Bima 
inhabited the west coast of Bima Bay, and were called Dou Donggo people (literally people who live in the highland or faraway land). Citing Chambert-Loir's Syair Kerajaan Bima (1982), Just (2001) stated that within the Dou Donggo there are two groups: Donggo Ipa (living on the west coast of Bima Bay, which is now part of Donggo subdistrict of Bima district) and Donggo Ele (now situated around Wawo, a mountainous sub-district of Bima district). Currently, both groups speak a common language (Bim.: Nggahi Mbojo). Another group of people called Dou Sambori in the Wawo region speak a different dialect of the Bima language.

Based on his knowledge of oral histories, Ismail (2004, 23-28) argues that during Bima's earliest era, there were two periods prior to Islam: naka and ncuhi. Naka describes a form of hunter-and-gatherer society where people moved from one place to another gathering food. At the time, they adhered to an indigenous animistic belief (Bim.: makakamba makakimbi, literally light flickering). The Bima people at the time believed in spirits (Bim.: parafu) who resided at special places like springs, large trees or large rocks (Bim.: parafu ro pambora). Ismail (2008, 38-39) said that parafu were believed to grow old and desire food so that the local people were required to bring offerings (Bim.: pasili) and take water from their parafu ro pambora before proceeding to life-cycle and healing rituals (Bim.: oi mori, literally 'water that bestows life') (Prager 2010, 17). ${ }^{7}$

In the era of ncubi, or chiefdom, there were five chiefs. The five chiefs administered and controlled different areas, but coordinated amongst themselves: Ncuhi Parewa in the south, Ncuhi Banggapupa in the north, Ncuhi Padolo in the west, Ncuhi Dorowani in the east, and Ncuhi Dara in the centre of Bima. Before the founding of the Bima kingdom, all the chiefs agreed to form a united territory under the leadership of Ncuhi Dara. In the eleventh century AD, the legendary Sang Bima, from the Medang kingdom (or Mataram), came and helped to advance the institution of chiefdom or ncuhi. Subsequently, Ncuhi Dara and others began to recognize the form of the royal kingdom. ${ }^{8}$ Although Sang Bima returned to Medang kingdom, he maintained contact with Ncuhi Dara because he married a local woman (Chambert-Loir 2004; Ismail 2004, 2008; R. Salahuddin 2004, 51). ${ }^{?}$

In the Ceritera Asal Bangsa Jin dan Segala Dewa-Dewa (The Story of Jinns and Gods), Chambert-Loir (1985a, 2004, 51-53) explained the mythology of the Bima kingdom. The book tells of Sang Bima, one 
of the sons of Maharaja Pandu Dewata, the Lord of the Heavens in the Mahabharata epic. Sang Bima was a traveller who met a beautiful maiden on his journey. He fell in love with the girl and slept with her. Bima realized that he slept with his daughter. The girl delivered two boys. Sang Bima advised his daughter that she should abandon her babies in the river and she followed his instruction. But the two newborn babies were swept away in the river bay and became stranded on Sumbawa island (Lewis 2010). The story continues that the local people found these two babies and gave them to Ncuhi Dara. The first baby was named Indra Zamrud and the second, Indra Kumala. Indra Zamrud was the adopted son of Ncuhi Dara. Indra Kumala was adopted by Ncuhi Dorowoni. Based on the local tradition of consensus (Bim.: karawi kaboju), all chiefs agreed to nominate Indra Zamrud as the first king of the Bima kingdom, following his father Sang Bima, while Indra Kumala reigned the kingdom of Dompu, which today is the Dompu district. The foundation of the Bima kingdom ended the period of Ncubi. The people of Bima subsequently entered a new era, that of a kingdom (Chambert-Loir 1982, 1985a, 2004, Ismail 2004, 2008; Zollinger 1851, 138-39). In the era of the Bima kingdom, all ncuhi became members of a customary council, which today is the Majelis Hadat Dana Mbojo (royal customary council). Although the story of Sang Bima is regarded as a myth, it is widely known as a feature of oral histories, and unanimously accepted as the story of the origin of the Bima people among local scholars including Siti Maryam, Hilir Ismail, L. Massir Q. Abdullah, Helius Sjamsuddin and Gani Abdullah. The manuscripts used to relate the story of Sang Bima are from Siti Maryam's personal collection.

Indra Zamrud became the first king of the Bima kingdom. In this period, the term Sangaji, locally translated as the son of a jinn, was introduced to refer to a king. ${ }^{10}$ Chambert-Loir $(2004,66,131)$ found that the name 'Jan wa Manjan,' the forebear of Sang Bima, is probably derived from the word 'jann,' referring to jinn in the Qur'an. Chambert-Loir $(2004,66)$ concluded that Islamic principles on the creation of the universe and human beings, as well as other creatures, had influenced the writing of Cerita Asal, which records the history of early Bima. Indra Zamrud was the first Sangaji or king. However, it was in the reign of King Manggampo Jawa, around the fourteenth century $\mathrm{AD}$, that the Bima kingdom developed. Manggampo Jawa was the son 
of Indra Sangaji Terati, who was from the royal family of the Medang kingdom in Java. He is called 'Manggampo Jawa' meaning 'he who united Jawa or Java.' At that time, King Manggampo Jawa pioneered the local adaptation of Sanskrit in the writing of local manuscripts, and the manufacture of bricks, daggers and spears (Ismail 2004, 2008).

Ismail (2004) noted that Ma Wa'a Paju Longge, the twelfth king of Bima in the fifteenth century, started to orient political relations towards the Gowa kingdom in Sulawesi island. At that time, the Gowa kingdom was experiencing its golden age, under King I Mariogau' Tunipalangga (r. 1546-1655). Ma Wa'a Paju Longge went to Gowa to study the science of government and other knowledge. Then he sent his two brothers, Ma Wa'a Bilmana and Manggampo Donggo, to Gowa. Since then, the political system of government, agriculture, trade, shipping and commerce followed the prevailing system in Gowa. When Ma Wa'a Bilmana and Manggampo Donggo obtained power, the system of paddy cultivation, shipping and commerce grew rapidly. Ships and boats increased in number and quality, resembling the navigation and commerce of Gowa.

This cooperation enhanced the security of the two kingdoms. Army and marine facilities were updated. The Bumi Renda was the commander of the army, and Rato Pabise acted as admiral to the navy (Ismail 2004, 42; R. Salahuddin 2004, 134-36) (Rato is an honorific title and Pabise is presumably from the Makassar loanword pabiseang, literally meaning sailor). The Gowa kingdom also impacted the culture and arts of Bima, and the foundation of positions such as Sultan; Raja Bicara (also called Tureli Nggampo, the head of the ministerial body); Tureli (Minister); Jeneli (sub-district head); and Gelarang (village head). These positions became officially installed during the period of King Manggampo Donggo in the seventeenth century (ChambertLoir 1982, 1985a, 2004, 53; Chambert-Loir and R. Salahuddin 2000; Ismail 2004, 2008; Tajib 1995, 93-94).

Tajib $(1995,90-91,488)$ wrote that there was a succession rule within the Bima kingdom at that time that if a king died and had no son, then the position would be given to the eldest brother. After King Ma Wa'a Paju Longge (the twelfth king) died and had no sons, his eldest brother, Ma Wa'a Bilmana, succeeded him. Ma Wa'a Bilmana initially accepted the position as the thirteenth king, but handed his crown to Manggampo Donggo, his younger brother. The following is the story 
behind the succession, as recorded in Bo' Sangaji Kai (Chambert-Loir and R. Salahuddin 2000, 3; Ismail 2004; Tajib 1995, 90-91, 488). In the book, Ma Wa'a Bilmana said to his brother Manggampo Donggo:

Hai paduka adinda, adapun nama Sangaji ini sudah diletakkan oleh orang Bima kepadaku, maka sekarang ini akulah meletakkan nama Sangaji kepadamu. Daripada awalnya sampai datang kepada akhirnya, anak cucu daripada paduka adinda menjadi tuhan dan anak cucu daripadaku menjadi hamba kepada nama Sangaji ini.

Hi my lord brother, the people of Bima already chose me as king, so now I bestow it over to you as king. From the beginning to the end, the offspring of you become lord and mine become subject to you.

As a result, Manggampo Donggo became Sangaji or king and $\mathrm{Ma}$ Wa'a Bilmana took the position of Raja Bicara, the royal office that he established (Chambert-Loir and R. Salahuddin, 1999: iii), which resembled tupamabbicara, the position of the King of Tallo in Sulawesi, literally the speaker of the kingdom (Cummings 2010). Siti Maryam told me the reason behind the willingness of Ma Wa'a Bilmana to give up power to his younger brother, Manggampo Donggo. 'Ma Wa'a Bilmana did that on behalf of the people. He believed that he had to go down to the earth to become the person-in-charge administering internal affairs of the Bima kingdom,' recounted Siti Maryam. The legendary story of power exchange was recorded in the oath of Bilmana (Bim.: Sumpah Bilmana) (Ismail 2004, 40 and 240; Tajib 1995, 9091). ${ }^{11}$ The oath reads as follows:

\section{Bilmana oath to the people}

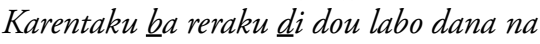

Indo kapo ra-a saciri ma kamorina weki, saraka nu-u ma ndundu ma mbonci

kantuwuna na su-u sawale ku ra katupa $\underline{\text { ba saraba, }}$

Ndei ru-u taho ro ncibi kai dana

ro rasa, Katohoku weki sura dou mori

na $\underline{b} a$ rasa

I pledge with my tongue to you my people,

a mouthful of blood that bestows life,

until the next generations,

the ruler's provisions will be adhered to and upheld,

for the well-being and prosperity of the nation,

no matter it will disgrace me,

as long as for the interest of the people and nation. 


\section{Bilamana oath to his younger brother, Manggampo Donggo}

Indo kapo ra nggahi sake $\underline{b}$ a ita dohu dua ma tada ndei kawara kantuwu $\underline{b}$ a nu-u mandundu, Aina du lepi rawi raka lapa, Selasi nggadi ba rawi ma ncemba, Mambentu angi ba ra ka sabua ba sara. Na wara sima ka caba na maci rawi ra sake, Na wari ro sai ku $\underline{b}$ a sake ra renta cua taho, Sarumbu na so-o lao bune sia, Na leli lelo lao bune lili,

Na tambua tatombu lao bune kalubu, Moda karapa di ntada dou marepa.

As for the agreement made by the great lords, it must be remembered from generation to generation:

Do not question something that has been set, even though you disagree with the king, you have to remain loyal.

Anyone who cancels or criticises the oath will be condemned by the oath itself.

His body will be crushed like salt, melted like wax, float like dust, vanished from the sight of the crowds.

In the period following the declaration of the Bilmana oath, the descendants of Manggampo Donggo became the successors to the Bima kingship, until the time of the Islamic era in the seventeenth century. ${ }^{12}$ The descendants of Ma Wa'a Bilmana were appointed as Raja Bicara (the speaker for the king and head of ministerial council). Throughout her works, Siti Maryam claims that Ma Wa'a Bilmana and Manggampo Donggo worked together to developed the Bima kingdom. The two developed agriculture and livestock by opening new fields for farming for the prosperity of the kingdom and the people.

At the end of the sixteenth, according to Siti Maryam (2004), the kingdom of Bima began to evolve into a crowded commercial centre in the eastern archipelago, with links to the Gowa and Ternate kingdoms. At that time, the kingdom of Bima was a rice exporter together with Lombok. Developments in the fields of literature, art and culture were bright. Manggampo Donggo introduced characters, which he learned from Gowa (Mak.: toa jangangjangang), which eventually became the distinctive Bima script. ${ }^{13}$ 


\section{The Coming of Islam}

As noted by Siti Maryam at the beginning of this paper, despite the fact that the descendants of the Ma Wa'a Bilmana and the Manggampo Donggo lived in harmony for centuries, a violation against the legendary Bilmana oath occurred at the beginning of the seventeenth century. Ma Ntau Asi Peka or 'Salise' (the Raja Bicara and brother of Ma Ntau Asi Sawo at the time), as mentioned in the beginning of this paper, took power by killing the prince (Bima.: Jena Teke) while hunting in the scrub of Wera. For this reason, the prince's posthumous name is $\mathrm{Ma}$ Mbora di Mpori Wera (he who was lost in today's Wera sub-district of Bima). Ismail (2004, 45-53) wrote of the legendary story in the period of king Ma Ntau Asi Sawo in the early 1600s, when the Bima kingdom signed a memorandum of understanding with the Gowa kingdom, stating that the Bima kingdom wanted to accept Islam, as the Gowa kings had already embraced the religion in 1605 and cut off trade relations with the Dutch (See also Tajib 1995). Sadly, Ma Ntau Asi Sawo died before he embraced Islam. Prior to his death, he appointed his eldest son to be the next king, although he was still a child. Salise killed the prince and took over the throne.

Both Tajib and Ismail claimed that the brother of the dead prince named La Ka'i was safe, and put secretly in exile by a number of his loyal allies in the village of Kalodu, located in what is today known as Sape. During his exile, La Ka'i and his companions, including Lambila (the son of Bilmana), Bumi Jara and Manuru Bata, visited four traders in the capital of Sape who were from the kingdoms of Gowa, Tallo, Bone and Luwu of Sulawesi. Daeng Mangali, the head of the traders, came not only for trade but also to spread Islam to the local ruler in Sape (Ismail 2004, 91; Tajib 1995, 111). After meeting with these traders, La Ka'i decided to embrace Islam, and here the versions differ on the dates, somewhere between 1619 and 1621. Tajib $(1995,110)$ gives the year as 1620, Ismail $(2004,52)$ said around 1619 , while Siti Maryam gives a date of 1621 (Chambert-Loir and R. Salahuddin 2000). Tajib $(1995,110)$ and Ismail $(2004,52)$ claimed that La Ka'i and his loyalists embraced Islam in Sape and returned to the Kalodu village of Sape to build a mosque called Sigi Kalodu (sigi is a Makassar loan word, masigi). From the Kalodu village, La Ka'i asked the Gowa kingdom to send military expeditions to Bima in order to restore his power.

According to Siti Maryam, however, La Ka'i embraced Islam during 
his exile in Gowa of Makassar on 7 February 1621, where he took an Islamic name, Abdul Kahir, and married the sister of the Gowa sultan's wife (Chambert-Loir and R. Salahuddin 2000; Hitchcock 1983, 35; Noorduyn 1987b). Becoming a Muslim was allegedly compensation for the request of La Ka'i to the Gowa king for military assistance to restore his throne in Bima. After his conversion, La Ka'i asked for the Gowa kingdom to send a military expedition to defeat the traitor king, Salise. Noorduyn (1987b, 317, 319), based on the Dutch sources and a lontara' (Makassar manuscript), noted that Bima was defeated by several military expeditions of the Gowa kingdom in 1618 and 1619 (See also Cummings 2010, 8). Nevertheless, La Ka'i (known by his title as Ruma-ta Mantau Bata Wadu) failed to placate his relatives and the people who were against the Gowa intervention. The Gowa forces came in 1632 to fight this local unrest. In the second expedition in May 1633 and after considerable bloodshed, the Gowa kingdom restored La Ka'i as the Bima king as noted in the beginning of this paper. Noorduyn (1987b) concluded that the defeat led to the Bima kingdom being forced to provide tribute and bridegrooms to the Gowa kingdom.

The following is the account of the process of Islamization in Bima written in the ancient Makassar manuscripts (Mak.: toa jangangjangang), cited by Noorduyn (1987b, 317, 319):

Nanisuro I Kare Bagia angku-taqnangi Karaenta pannguqranginna ri butta i baqleang Dima Dompu Sambawa, ka betana ri Karaenga Tu-Ammenangri-agamana. Nanakana Karaenta: ‘Nibeta-kapereki, nipasallangi, nipareqngasengi ata ri Karaeng, passanngalinna Sanggaraq, ka nimaradekangi ri Karaenga, ka ia uru ampalantei qBonto. Apajintu Dima Dompu namaqbuisiq tungguna taung-taung ri Karaenga nanipappalakki todong tungguna pakala waki-jarang. (Add. 1235 If. 34v)

Kare Bagia was instructed to go and ask our Lord what he remembered about the overseas countries of Bima, Dompu, and Sumbawa, as they had been defeated by Karaeng Tu-Ammenang-ri-agamana. The Lord said: 'They were defeated as infidels, were made to embrace Islam, and were all of them enslaved by the Karaeng except for Sanggar, Sumbawa which (country) he gave its freedom because it had been the first to allow him to come ashore'. Bima, Dompu, Naantu and Sumbawa used to pay an annual tribute to the Karaeng, or lord, and were also regularly asked to provide grooms.

Noorduyn $(1987 b, 317,319)$ translated the phrase 'Nibeta-kapereki, nipasallangi, nipareq-ngasengi ata ri Karaeng', as 'they were defeated as 
infidels, were made to embrace Islam, and were all of them enslaved by the Karaeng (Makassar chief).' As noted at the beginning of this paper, Siti Maryam agreed that the Bima kingdom was defeated by the Gowa kingdom. But she offered the 'real' reason for the Gowa's intervention: to restore the power of her family. The Gowa kingdom fought against the traitor king, Salise, who was Raja Bicara, and not supposed to become the Bima king, in accordance with the ancient oath of Bilmana (see Sumpah Bilmana).

Siti Maryam also said that it was the prince of Bima, La Ka'i, who asked the Gowa kingdom to send military expeditions to Bima to conquer Salise and his loyalists. Likewise, Ismail (2008) asserted that the aim of the Gowa military expeditions to Bima at the time was to regain the power of La Ka'i from Salise, who had seized the throne after the assassination of La Ka'i's brother, Prince Mbora Di Mpori Wera. This version further argues that, due to the military assistance, the new king provided tribute to the Gowa kingdom. Siti Maryam suggested that Noorduyn, by relying solely on Makassar sources, might have failed to understand the reason why La Ka'i asked for the military expeditions of the Gowa kingdom and, she noted, he did not mention the existence of the Bilmana oath. Noorduyn (1987b) argued that the intermarriage between the two sultanates was seen as a political means to further disseminate the Gowa influence over Bima. Gowa established Makassar inhabitants (Mak.: mokkeng, from the Arabic word muqim) in Bima and, according to Noorduyn (1987b), the Gowa king treated the local people as slaves. The local rulers had the responsibility to conduct Friday prayer services. ' $\mathrm{He}$, Karaeng Matoaya, established the Friday service in those overseas countries. The Karaeng hope(d) to gain reward by appointing mokkeng, and then setting them free. Just those people called mokkeng were free, and the commoners were slaves' (Cummings 2010, 8; following Noorduyn 1987b, 318). In reverse, Siti Maryam concluded that the intermarriage was a medium for strengthening the family relations between the two kingdoms, particularly after the process of Islamization. She also opposed Noorduyn's (1987b) conclusion that the Gowa king enslaved Bima people at the time.

Whatever the background that informed the coming of Islam to Bima, the power of the Gowa kingdom's ruler over Bima was widespread after the successful military expeditions. Due to this political dominance, the Gowa kingdom sent Datuk ri Bandang and 
Datuk ri Tiro (Dato di Banda and Dato di Tiro for Bima case), who had key roles in Gowa's Islamization, to help the new Bima king further disseminate Islam in Bima (See also Chambert-Loir 1985b; ChambertLoir and R. Salahuddin 2000, xvi; Hitchcock 1996, 40). ${ }^{14}$

When La Ka'i regained his power, the title Sultan became popular and replaced that of Sangaji. Bima entered the next era, that of the sultanate. Upon completion of their religious mission (Ind.: dakwah), Datuk ri Bandang and Datuk ri Tiro were asked to return to Makassar by the Gowa Sultan. The Datuk advised his sons, Ince Nara Diraja and Ince Jaya Indra, to remain in Bima and continued to disseminate Islam to the Bima people (Chambert-Loir and R. Salahuddin 2000, 57; R. Salahuddin 2004, 22-23). It was Datuk Maharajalela (the grandson of Datuk ri Bandang) who persuaded the Bima king Sultan Abi'l Khair Sirajuddin $(1640$ - 1682) to declare Islam as the formal religion of the Bima kingdom on 5 July 1640, or 18 Rabi'ul Awal 1050 $\mathrm{H}$ of the Islamic calendar (Chambert-Loir 1985b; Chambert-Loir and R. Salahuddin 2000, 57-60). The date of 5 July 1640 has been the anniversary of the Bima Sultanate (Ind.: Hari Jadi Bima) since the early 1990s. ${ }^{15}$

During the period of Sultan Abi'l Khair Sirajuddin (1640-1682), Islam gained an important role within the Bima Sultanate. In 1701, according to Siti Maryam, the fifth Bima Sultan, Sultan Hasanuddin Ali Syah (1696-1731) strengthened the formal position of Islam as one of the councils within the political system of the Bima Sultanate. At the time, there were three councils: 1) the ministerial council (Majelis Tureli or sara-sara), which was responsible for administrative affairs and led by Raja Bicara. ${ }^{16}$ The council consisted of six ministers (Bim.: tureli), six sub-district head (Bim.: jeneli), 12 experts in many skills (Bim.: bumi), and village heads (Bim.: gelarang); 2) the customary council (Majelis Hadat or sara tua), which was in charge of local custom issues and consisted of 12 representatives (this council replaced the institute of ncuhi from the era of the Bima kingdom regarded as the pre-Islamic era). Bumi Lumah Rasa Na'e was the head of this council (Abdullah 2004, 120-22), which had the responsibility to appoint the new sultan, and; 3) the religious council (Majelis Agama or sara huku), led by a Kadhi (Bim.: Kali, literally a Muslim judge who rendered decisions according to the Islamic law or Sharia, the canon law of Islam). The Kadhi was assisted by four khatib (literally a person delivering sermon), namely 
khatib tua (the head of khatib), khatib karoto (literally the throat of khatib meaning the deputy of khatib), khatib lawali (literally the chest of khatib meaning below the khatib deputy) and khatib to'i (literally small khatib). In 1770, when the eighth Bima Sultan, Sultan Abdul Kadim (1751-1773) built the grand mosque of the Bima Sultanate, the religious council was responsible for appointing mosque officials. The mosque officials included lebe, or the Imam, and cepe lebe (deputy Imam) across Bima (Abdullah 2004, 122, 170; Prager 2010, 13; R. Salahuddin 2004, 100).

Despite the differences in their responsibilities, the councils were politically equal before the Bima Sultanate. The religious council (Majelis Agama or sara huku) in particular became instrumental in the further Islamization of Bima society (Prager 2010, 13). Dae Syarifuddin or Dae Deo explained to me that the symbolic expression of the equality of the three councils was illustrated in the easternmost palace, the former palace of Raja Bicara (Bim.: Asi Kalende), located in today's Pane village of Rasanae sub-district. ${ }^{17}$ As can be seen from the photo (Figure 2), there is a carved dragon's head above the main entrance, which sits on a pole supported by three pillars representing three councils (Hitchcock 1996, 63-64). During the reign of Abdul Kahir's son, Sultan Abi'l Khair Sirajuddin, the second Bima Sultan (1640-1682), these three councils provided the code of conduct for the rest of the Bima people. As Islam became the formal religion, Bima Muslims showed a strong social, political, and cultural affinity with their fellow Malay and Makassar Muslims (Hitchcock 1996, 173). ${ }^{18}$

As a result of the Islamization process, the relationship between the sultanate of Bima and the sultanate of Gowa, Makassar was very close in terms of marriage. Chambert-Loir and R. Salahuddin (2000, 60) noted that the intermarriage between Gowa noblewomen and the sultans of Bima took place until the sixth sultan of Bima (ChambertLoir and R. Salahuddin, 1999). As the marriage was political (Noorduyn 1987b), the relationship between Gowa and Bima strengthened. The two sultanates created a joint military cooperation in the battle against the Dutch for monopoly of the spice trade in the eastern archipelago (R. Salahuddin 2004). At that time, Gowa rivaled the Dutch East India Company (VOC) for control over the spice trade in Maluku (Andaya 1981), and over Buton set as an important source of slaves (Cummings 2010, 7). 
In 1667, the Bugis noble Arung Palakka (later Sultan Sahaduddin) and his Bone and Soppeng rebels, another two kingdoms of South Sulawesi, joined forces with the VOC and defeated the Gowa Sultanate during the battle known as the Makassar War in 1669. The new overlords then divided greater Gowa's empire, while retaining Makassar as its capital. In this new arrangement, the VOC took over Makassar's trade, while Arung Palakka settled in Makassar to rule South Sulawesi's internal affairs (Andaya 1981; Bulbeck 1990). After the defeat of the Gowa Sultanate by the Dutch in 1669, hundreds of gallarang (Makassar noblemen) fled Gowa (Andaya 1984, 208-27; Just 2001, 76). Many of them arrived in Bima, and married Bima women (gallarang became gelarang in local use to refer to village head).

In the following years, after the VOC had defeated Makasar, Sultan Abi'l Khair Sirajuddin (1640-1680) was forced by the VOC to sign an agreement for unilateral trade. In 1792, Sultan 'Abdul Hamid Muhammad Shah (1773-1817) was persuaded to sign a definitive contract, becoming a protectorate of the VOC thereafter (Noorduyn 1987a, 56). Dutch colonialism intensified in 1908 and influenced fundamental changes within the local political order of Bima (Prager 2010, 15). As the result of direct Dutch colonial rule, the political relationship between Gowa of Makassar and Bima ended. The intermarriage between the two sultanates also ceased. In contrast, the relationship between the Bima Sultanate and the Dutch became politically close.

\section{Conclusion}

This paper has examined the way local interlocutors understand the history of Bima Islamization. I found that their knowledge, in particular that of Siti Maryam, in reference to Bima vernaculars (e.g., folktales and $\mathrm{Bo}$ ), is politically constructed. As heir to the Bima Sultanate, Siti Maryam has the privilege to preserve the remnants of the Bima Sultanate. This politically motivated project aims to standardize the narration of Bima kings and Islamization in favor of sustaining the authority of the Bima Sultanate. The aim of Siti Maryam in the transliteration, translation and interpretation of local manuscripts has seemingly been to create a unity of the local narratives, and coherence of the narrative discourse situated precisely between 'myth' and 'history.' The narratives are laid out in the local Bima documents (e.g., Bo'Sangaji 
$K a i)$, and populated by different actors and qualities, as well as different times and places, one of which follows the canonical scheme.

Nonetheless, the transliteration and translation of the Bima historical manuscripts vary from one period to the next across both space and time, and are sometimes reconstructed as well as contested by other people. Even within the royal family of the Bima Sultanate, as exemplified by Siti Maryam and Hilir Ismail, variation occurs in the understanding of Bima Islamization. These differences, including the known origins of the Bima people, occur between scholars because the sources they use are varied. This is akin to the analysis of Fox and Sather (1996: 5), who said that access to one's origins (genealogy or pedigree) requires various ways of ascertainment: dreaming, contact with spirits, the recitation of formulaic wisdom, the witness of the elders, or the presentation of sacred objects as proof of connections to the past. Each of these means can enable us to present information of the past.

Although notions of origin may vary from one person to another, they are generally cited in terms of 'common metaphors based on recognizable cognate expressions.' I found that the story of Sang Bima (or Hikayat Sang Bima), as described in the paper, has turned out to be the common metaphor to illustrate the story of the founder of the Bima kingdom, and become the narrative of the origins and ancestry of the contemporary Bima society. This is a distinctive Austronesian characteristic whereby, in order to know the origins of a given society, the easiest access is the story of the elders available in the forms of manuscripts or narratives chants (Fox and Sather 1996).

The presence of the Hikayat Sang Bima in a Malay-influenced society like Bima is simply a story of the origin of Bima people that can be seen as a 'historically factual' (Lewis 2010, xx). To understand the story, as I borrow Lewis's postulate (2010), who further argues, is to know in the first place the culture of the people who produced them. As each part of the story in the Hikayat Sang Bima is interrelated, I argue that the story is a sequence of one stage to another towards the full completion of today's Bima people. Notions of ancestry, place and alliance allow us to define individuals and social groups in Bima. It is worth noticing that the availability of the historical account becomes the ideological justification of cultural sub-divisions of Bima people (e.g., highlands and lowlands), the socio-political rivalry between social groups (e.g., the Sultan and Raja Bicara), social stratification, 
and political positions of different people from the time of pre-Islamic Bima to the present.

The historical facts that make up the present social strata show that social status is important in society. Social status is even considered Islamic in the sense that Islam is used in the origin stories and legitimizing rituals. For example, the royal family have used the festival of the coming of Islam to Bima (i.e., Hanta U'a Pua) as 'an Islamic festival,' in order to sustain the special status of the royal family and the Malay descent.

The festival is a tribute to the early Malay preachers who brought not only the religion of Islam but also a new way of constructing history and expressing identity through literary tradition. They were a key player in shaping the religious conversions in Bima, in institutionalizing Islam in the region, and in creating the local manuscripts. Accordingly, local people regard the manuscripts as a text of memory, and extremely important in the writing of Bima's collective folk stories in reference to genealogy of Bima kings from the beginning of the Bima kingdom to the Islamic era. $B o$, the local term for the manuscripts, has become a historical text of linkage between the past and the present in reference to the contemporary construction of Bima people. The widespread use of the manuscripts by local authors has elevated people of Malay descent to a respected position in the lives of Bima people.

To conclude, I argue that the reluctance of Siti Maryam to accept the conclusion of Noorduyn (1987b), as outlined in the beginning of this paper, shows her political standing point to provide certain historical accounts as the 'true' version of Bima Islamization. Siti Maryam understands that the Gowa kingdom defeated Bima by force in the early period of Bima Islamization in order to return the throne to the prince, Siti Maryam's ancestor. Accordingly, Islam is regarded as the religion of liberation for her family. In contrast, people of Malay descent are considered to be 'holy,' as their ancestors came to spread Islam by means of peace. 


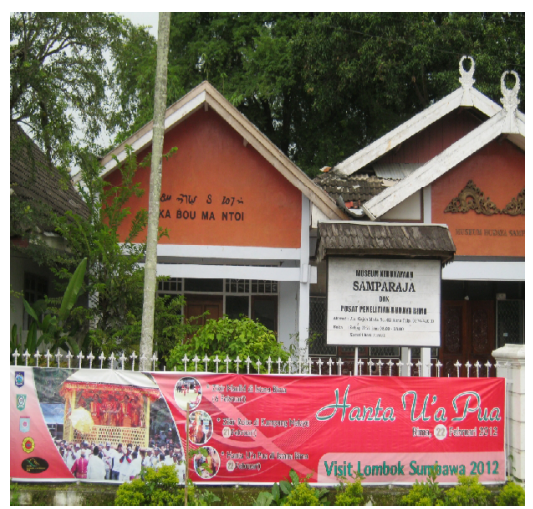

Figure 1. The museum of Samparaja is situated in Gadjah Mada street of Rasanae sub-district. The inscription of the orange gable is written both in Bima script and Latin scripts, saying $\mathrm{Ka}$ Bou Ma Ntoi meaning to preserve the old.

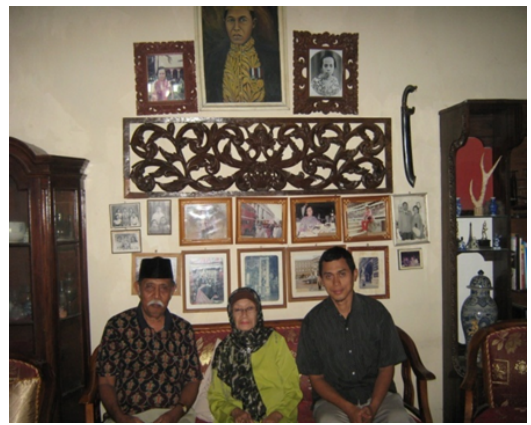

Figure 2. Dae Syarifuddin or Dae Deo (the descendant of Raja Bicara Muhammad Kuraisy) and Siti Maryam or Ruma Mari (the descendant of Sultan Muhammad Salahuddin) as well as author.

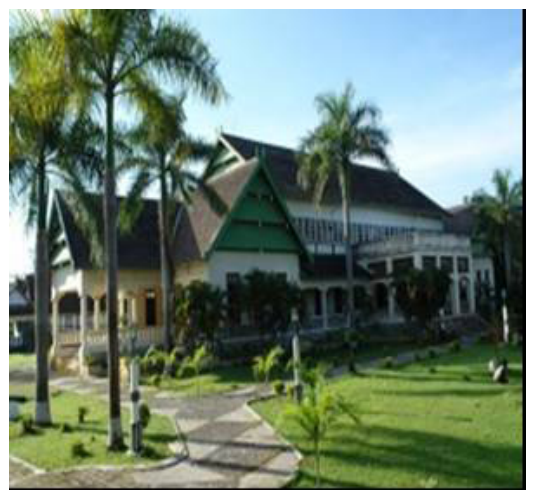

Figure. 3. Asi Mbojo (the Sultan palace) or also called Asi Bou (new palace), the location of Asi Mbojo museum. 


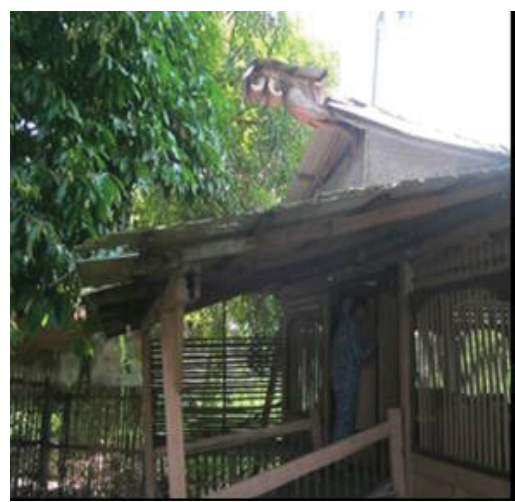

Figure 4. The former palace of Raja Bicara called Asi Kalende (the palace of watermelon) (Zollinger, 1847: 202) situated in today's Pane village.

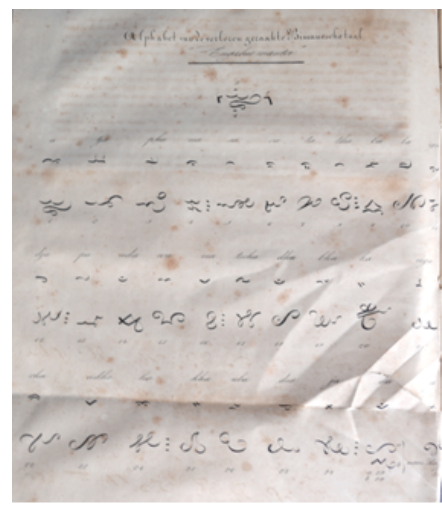

Figure 5. The Bima script resembling some letters of the old Makassar script (Mak.: toa jangang-jangang) (Zollinger, 1850: 135). Thanks to Prof. Campbell Macknight, I have access to the book.

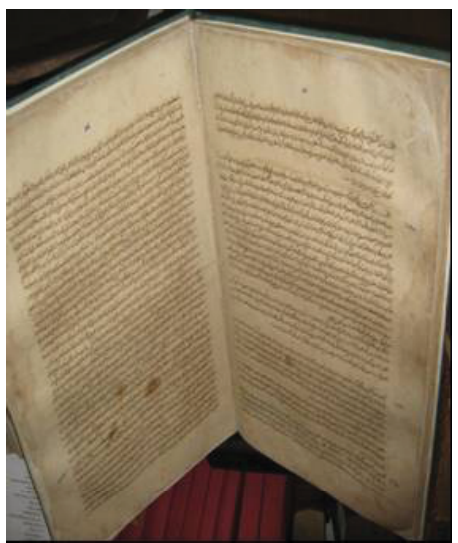

Figure. 6. Some pages of the original manuscript of Bo' Sangaji Kai. 


\section{Endnotes}

- The earlier version of the paper was titled 'Islam Constructed: How the Bima Muslims construct their historical Islamization'. The abstract of the paper was previously submitted to the International Conference of 'Tethering The Past', held at The University of Sydney, 28-29 November 2013. But the original source of this paper was derived from Chapter Two of my PhD Thesis titled 'Being Muslim in Bima of Sumbawa, Indonesia: Practice, Politics and Cultural Diversity', submitted to the Department of Anthropology, the School of Culture, History and Language (SCHL), College of Asia and the Pacific (CAP) for the degree of Doctor of Philosophy, The Australian National University in August 2014. My PhD was made possible by a scholarly funded by Australian Research Council Discovery Project DP00881464 'Being Muslim in Eastern Indonesia: Practice, Politics and Cultural Diversity', with Chief Investigators Professor Kathryn Robinson and Dr Andrew McWilliam in the Anthropology department, the ANU College of Asia and the Pacific (CAP). I thank to both of them for their valuable comments of this paper

1. In Bima, a female heir is possible when the male heirs are still young. In the previous period, the Bima Sultanate used to have a female ruler namely Kumala Shah (or Kumala Bumi Partiga) from 1747 to 1751. Kumala Bumi Partiga became the first sultanah (female sultan) because Abdul Kadim, her little brother, was only 13 years old at that time. When Abdul Kadim was 17 years old, the crown was passed to him in 1751 and he became the eighth Sultan.

2. Bo' Sangaji Kai (Chambert-Loir and R. Salahuddin 2000) is one of the most recent published Jawi manuscripts on Bima, which most of its sources are derived from the Samparaja Museum.

3. The term Jawi is an adjective from the Arabic noun 'Jawah', which may originate from the term 'Jawadwipa', the ancient name for Java. The Arabs may have used the term to address the people of Southeast Asia who went to Mecca for the Hajj pilgrimage. Sila $(2005,60)$ found the term Jawi was used to refer to the non-Sayyid people in Cikoang, South Sulawesi compared to the Sayyid (or the Hadhrami of today's Yemen) who claim descent from the Prophet Muhammad. Currently, the term Jawi is used to refer to the standard script for the Malay language, but since it has been replaced by the Latin alphabet, Jawi has been relegated to a script used for religious and cultural purposes. Day-to-day usage of Jawi is maintained in Malay-populated areas including Pattani in Thailand and Kelantan in Malaysia, as well as by some of the Muslim population of the southern Philippines (Simpson 2007, 356-60).

4. Among the Bugis society in Sulawesi the manuscripts are treated by their owner as supernatural power (Ind.: keramat). They also have suspicion to foreigners because of experiences of researchers and others stealing the manuscripts (Robinson and Paeni 1998, 171).

5. Chambert-Loir $(2004,21)$ thanked L. Massri Q. Abdullah, the heir of Raja Bicara Muhammad Kuraisy, who provided a number of pages from Bo' Bicara Kai for the publication of Cerita Asal Bangsa Jin dan Segala Dewa-Dewa. Chambert-Loir (2004, 31) also thanked Helius Sjamsuddin and Gani Abdullah who provided the excerpt of the manuscript written in Bima language about the story of Indra Zamrut and Indra Kemala, the forebear of Bima and Dompu kings. I received two volumes of the copy of the transliteration of Bo' written by Helius Sjamsuddin from Muslimin R. Effendy, an archaeologist from the La Galigo Museum during my fieldwork. Helius named his transliteration as the Bima manuscripts (Bim.: Bo' Mbojo) without identifying what type of $B o^{\prime}$ he was referring to. As he received the manuscript from L. Massri 
Q. Abdullah, I assume that his transliteration is derived from some of Bo' Bicara Kai.

6. The expelled nobles are locally known as makalosa weki. Hilir Ismail is the descendant of Daeng Pabeta, known to be the nobleman who used to rival the Bima Sultan in the past, which might be why Hilir Ismail was expelled. In Bo' Sangaji Kai, the first nobleman from the line of Raja Bicara who entered this social category is Ahmad Daeng Manasa (Chambert-Loir and R. Salahuddin 1999, 609). I read some books written by Hilir Ismail distributed in the primary school of Bima municipality where my children were enrolled as students. I was helped in obtaining these books by Alan Malingi, a co-writer of Hilir Ismail including; Peran Kesultanan Bima dalam Perjalanan Sejarah Nusantara (The Role of Bima Sultanate in the History of the Archipelago); and Kebangkitan Islam di Dana Mbojo (Bima) (1540-1950)" (The Islamic Revival in Bima, 2008. Unlike Siti Maryam, however, the sources used by Hilir Ismail in writing his works are derived from both the manuscripts and oral histories. He did mention his sources were Jawi manuscripts but his family kept them secret and inaccessible to outsiders. Meanwhile, Siti Maryam, with the assistance of Chambert-Loir, wrote most of her books from the transliteration of the Jawi manuscripts she possessed and which are available in Samparaja Museum.

7. Prager $(2010,17)$ found: 'Today, following the long-standing agitation of Islamic reformers, most ritual performance offerings to the spirits - along with the concomitant cosmological ideas - have been vigorously pushed to the background, if not fallen into oblivion, particularly among the younger generation.' As I found, however, these ritual practices, like taking sacred water (Bim.: oi mori or 'water that bestows life') from places of spirits (Bim.: parafu ro pambora), are still observable, even for the Muslims residing in urban areas like Bima city where most reformist Muslims and hajj pilgrims reside.

8. Dara is now known as an urban village [Ind.: kelurahan] in Bima, where the bus terminal of Bima city is located.

9. All the scholars mentioned above agreed with the period of Ncuhi or chiefdom before the coming of Sang Bima from Medang kingdom. The Medang or Mataram Kingdom became the dominant power in Java and was a serious rival to the hegemonic Srivijaya empire. It was a Hindu kingdom that eventually replaced the Buddhist Srivijaya kingdom. But the kingdom was known as the 'reciprocal tolerance between the two Buddhism and Hinduism' (Coedes 1975, 126). Thus, the kingdom, based in Central Java and later in East Java, is seen as a syncretic Hindu-Buddhist kingdom, which flourished between the eight and tenth centuries CE.

10. Similarly, the term Sangaji was widely used to describe the local leader of coastal communities allied to the Tidore Sultanate. Presumably, the term came from Tidore, but further research is still needed. Sangaji is also a common term for ruler or key leader in West Papua and regions of Maluku.

11. I cited this legendary Bilmana oath from the books written by Abdullah Tajib (1995) and Hilir Ismail (2004). The above quotation is taken from the book of Ismail (2004, 240). Both Tajib and Ismail take the Bilmana oath into their consideration when analysing the ideological justification of current positions. Like Ismail, Tajib is a historian by training.

12. In Bo' Sangaji Kai, Chambert-Loir and R. Salahuddin (2000,3) used the posthumous names of Ma Wa'a Bilmana and Manggampo Donggo (Rumata Makapiri Solo for Ma Wa'a Bilmana and Rumata Ma Wa'a Ndapa for Manggampo Donggo) when describing the legendary Bilmana oath.

13. When visiting Balla Lompoa Museum in today's Gowa district of South Sulawesi in October 2011, I saw a museum display comparing toa jangang-jangang, lontara' and 
Malay script. Toa jangang-jangang is the ancient Makassarese script and is now very rare to find, including the one cited by Noorduyn (1987b). The lontara' script is descended from the Brahmi script of ancient India. But the name lontar' derives from the Malay word, lontar (palmyra palm leaf). The character of lontara' originates from the philosophy of sulapa' appa' (the square). It symbolizes the micro cosmos of the human body such as butta'(soil), pepe'(fire), je'ne' (water), and anging (wind) (Mattulada 1991, 68-69). The concept of sulapa'appa' is derived from the teachings of an Islamic Sufi order, or tarekat (Cited in Robinson and Paeni 1998, 186).

14. Chambert-Loir (1985b) preferred to use Dato' ri Bandang, and not Datuk ri Bandang. But he used Datuk ri Bandang in Bo' Sangaji Kai (1999). In Bima, it is written Dato di Banda or Dato Dibanta. Datuk is a Malay honorific title, which has two meanings: it refers to a male elder, or one's grandfather. Dato' or Dato is another variant used interchangeably with Datuk.

15. Scholars like Prager $(2010,16)$ postulated that 5 July 1640 is the year when La Ka'i, the first Bima Sultan, converted to Islam. On the other hand, Chambert-Loir and R. Salahuddin (2000) found that La Ka'i converted to Islam on 7 February 1621. 5 July 1640 is commonly known as the foundation of Bima Sultanate during the period of Sultan Abi'l Khair Sirajuddin. In the 1990s, the local legislature (DPRD) of Bima municipality agreed to proclaim the date of 5 July as the anniversary of Bima. Siti Maryam said to me that it was a political loss for her.

16. Through this role, Raja Bicara is also called Tureli Nggampo, which means he who unites: tureli or minister (turu means to direct and eli means the voice of the people) and nggampo, which means manager. Raja Bicara acted on behalf of the Sultan as the speaker in for interior affairs. He was elected by a traditional legislature called Majelis Hadat, or adat (custom) assembly. Raja Bicara is like a prime minister in modern presidential or semi-presidential countries, who is usually approved by the legislature and responsible for carrying out the directives of the president, and managing the civil service. At that time, Raja Bicara was in charge of the ministerial assembly locally referred to Majelis Tureli, who selected and dismissed members of his ministers (Prager 2010, 13).

17. In the era of Bima Sultanate, Bima people recognized two kinds of palaces, one belonging to Sultan and the other belonging to Raja Bicara. The first is called Asi $\underline{B}$ ou, meaning new palace, and the second is called Asi Kalende, Raja Bicara's palace. Asi $\underline{B} o u$ literally means new palace, which is now known as Asi Mbojo.

18. According to a legendary story, the origins of Bima kings are derived from a giant dragon, which married a god and gave birth to Bima kings in a place called Nissa Satonda (Zollinger 1851, 138). That is the reason why a dragon head became the symbol of Asi Kalende, and the main motive of the ancient Bima kingdom.

\section{Bibliography}

Abdullah, Abdul Gani. 2004. Peradilan Agama dalam Pemerintahan Islam di Kesultanan Bima, 1947-1957. Mataram: Lengge.

Andaya, Leonard Y. 1981. The Heritage of Arung Palakka: A History of South Sulawesi (Celebes) in the Seventeenth Century. The Hague: Martinus Nijhoff. . 1984. "Kingship Rivalry and the Role of Islam in South Sulawesi." 
Journal of Southeast Asian Studies 15(1): 22-42.

Bulbeck, F. David. 1990. "The Landscape of the Makassar War." Canberra Anthropology 13(1): 78-99.

Chambert-Loir, Henri. 1982. Syair Kerajaan Bima. Bandung: Ecole Française d'Extreme-Orient.

- 1985a. Ceritera Asal Bangsa Jin dan Segala Dewa-Dewa. Bandung: Ecole Française d'Extrême-Orient \& Angakasa.

_ 1985b. "Dato' Ri Bandang. Légendes de l'Islamisation de La Region de Célèbes-Sud." Archipel 29: 137-63.

- 2004. Kerajaan Bima Dalam Sastra Dan Sejarah. Jakarta: EFEO \& Kepustakaan Populer Gramedia.

Chambert-Loir, Henri, and Siti Maryam R. Salahuddin, eds. 2000. Bo' Sangaji Kai: Catatan Kerajaan Bima. Jakarta: École française d'Extrême-Orient \& Yayasan Pustaka Obor Indonesia.

Coedes, G. 1975. The Indianized States of Southeast Asia. ed. Walter F. Vella. Canberra: ANU Press.

Cummings, William. 2001. "Scripting Islamization: Arabic Texts in Early Modern Makassar." Ethnohistory 48(4): 559-86.

2010. The Makassar Annals. Leiden: Brill.

Fox, James J., and Clifford Sather. 1996. Origins, Ancestry and Alliance: Explorations in Austronesian Ethnography. Canberra: Dept. of Anthropology, The Australian National University.

Hitchcock, Michael John. 1983. "Technology and Society in Bima, Sumbawa, with Special Reference to House Building and Textile Manufacture." Ph.D. Dissertation. University of Oxford.

- 1996. Islam and Identity in Eastern Indonesia. Hull: University of Hull Press.

Ismail, M. Hilir. 2004. Peran Kesultanan Bima dalam Perjalanan Sejarah Nusantara. Mataram: Lengge.

- 2008. Kebangkitan Islam di Dana Mbojo (Bima): 1540-1950. Bogor: Penerbit Binasti.

Just, Peter. 1989. "Dou Donggo Social Organization: Ideology, Structure and Action in an Indonesian Society." Ph.D. Dissertation. University Microfilms International.

- 2001. Dou Donggo Justice: Conflict and Morality in an Indonesian Society. Lanham, MD.: Rowman \& Littlefield Publishers.

Lewis, E. Douglas. 1996. “Origin Structures and Precedence in the Social Orders 
of Tana 'Ai and Sikka." In Origins, Ancestry and Alliance: Explorations in Austronesian Ethnography, eds. James J. Fox and Clifford Sather. Canberra: ANU E-Press.

2010. The Stranger-Kings of Sikka. Leiden: KITLV Press.

Mattulada, H.A. 1991. "Manusia dan Kebudayaan Bugis-Makassar dan Kaili di Sulawesi." Antropologi Indonesia: Majalah Antropologi Sosial dan Budaya Indonesia 15(48): 4.

Noorduyn, J. 1987a. Bima En Sumbawa: Bijdragen Tot de Geschiedenis van de Sultanen Bima En Sumbawa Door. Dordrecht-Holland: Foris Publications.

- 1987b. "Makasar and the Islamization of Bima." Bijdragen tot de Taal-, Land-en Volkenkunde 143(2): 312-42.

Prager, Michael. 2010. "Abandoning The 'Garden of Magic': Islamic Modernism and Contested Spirit Assertions in Bima." Indonesia and the Malay World 38(110): 9-25.

R. Salahuddin, Siti Maryam. 2004. Hukum Adat Undang-Undang Bandar Bima. Mataram: Lengge.

Robinson, Kathryn May, and Mukhlis Paeni, eds. 1998. Living Through Histories: Culture History and Social Life in South Sulawesi. Canberra: Dept. of Anthropology, Research School of Pacific and Asian Studies, the Australian National University.

Sila, Muhammad Adlin. 2005. "Gender and Ethnicity in Sayyid Community of Cikoang, South Sulawesi: Ka’afah, A Marriage System among Sayyid Females.” Antropologi Indonesia: Majalah Antropologi Sosial dan Budaya Indonesia 29(1): 56-68.

Simpson, Andrew. 2007. Language and National Identity in Asia. New York: Oxford University Press.

Tajib, Abdullah. 1995. Sejarah Bima Dana Mbojo. Raba, Bima: Harapan Masa PGRI Jakarta.

Zollinger, Heinrich. 1851. Verslag van eene reis naar Bima en Soembawa, en naar eenige plaatsen op Celebes, Saleijer en Floris, gedurende de maanden Mei tot December 1847. Batavia: Bataviaasch Genootschap van Kunsten en Wetenschappen.

Muhammad Adlin Sila, Research and Development Agency of Ministry of Religious Affairs, Indonesia. Email: silaadlin2000@gmail.com. 
66 Muhammad Adlin Sila 


\section{Guidelines}

\section{Submission of Articles}

tudia Islamika, published three times a year since 1994, is a bilingual (English and Arabic), peer-reviewed journal, and specializes in Indonesian Islamic studies in particular and Southeast Asian Islamic studies in general. The aim is to provide readers with a better understanding of Indonesia and Southeast Asia's Muslim history and present developments through the publication of articles, research reports, and book reviews.

The journal invites scholars and experts working in all disciplines in the humanities and social sciences pertaining to Islam or Muslim societies. Articles should be original, research-based, unpublished and not under review for possible publication in other journals. All submitted papers are subject to review of the editors, editorial board, and blind reviewers. Submissions that violate our guidelines on formatting or length will be rejected without review.

Articles should be written in American English between approximately 10.000-15.000 words including text, all tables and figures, notes, references, and appendices intended for publication. All submission must include 150 words abstract and 5 keywords. Quotations, passages, and words in local or foreign languages should 
be translated into English. Studia Islamika accepts only electronic submissions. All manuscripts should be sent in Ms. Word to: http:// journal.uinjkt.ac.id/index.php/studia-islamika.

All notes must appear in the text as citations. A citation usually requires only the last name of the author(s), year of publication, and (sometimes) page numbers. For example: (Hefner 2009a, 45; Geertz 1966, 114). Explanatory footnotes may be included but should not be used for simple citations. All works cited must appear in the reference list at the end of the article. In matter of bibliographical style, Studia Islamika follows the American Political Science Association (APSA) manual style, such as below:

1. Hefner, Robert. 2009a. "Introduction: The Political Cultures of Islamic Education in Southeast Asia," in Making Modern Muslims: The Politics of Islamic Education in Southeast Asia, ed. Robert Hefner, Honolulu: University of Hawai'i Press.

2. Booth, Anne. 1988. "Living Standards and the Distribution of Income in Colonial Indonesia: A Review of the Evidence." Journal of Southeast Asian Studies 19(2): 310-34.

3. Feener, Michael R., and Mark E. Cammack, eds. 2007. Islamic Law in Contemporary Indonesia: Ideas and Institutions. Cambridge: Islamic Legal Studies Program.

4. Wahid, Din. 2014. Nurturing Salafi Manhaj: A Study of Salafi Pesantrens in Contemporary Indonesia. PhD dissertation. Utrecht University.

5. Utriza, Ayang. 2008. "Mencari Model Kerukunan Antaragama." Kompas. March 19: 59.

6. Ms. Undhang-Undhang Banten, L.Or.5598, Leiden University.

7. Interview with K.H. Sahal Mahfudz, Kajen, Pati, June $11^{\text {th }}$, 2007.

Arabic romanization should be written as follows:

Letters: ', $b, t, t h, j, h, k h, d, d h, r, z, s, s h, s, d, t, z, ', g h, f, q, l$, $m, n, h, w, y$. Short vowels: $a, i, u$. long vowels: $\overline{\mathrm{a}}, \overline{\mathrm{i}}, \overline{\mathrm{u}}$. Diphthongs: $a w$, ay. Tà marbūtāa: t. Article: al-. For detail information on Arabic Romanization, please refer the transliteration system of the Library of Congress (LC) Guidelines. 
ستوديا إسلاميكا (ISSN 0215-0492; E-ISSN: 2355-6145) بحلة علمية دولية محكمة تصدر عن مركز دراسات الإسلام والمجتمع (PPIM) بجامعة شريف هداية الله الإسلامية الحكومية بجاكرتا، تعنى بدراسة الإسلام في إندونيسيا خاصة وفي جنوب شرقي آسيا عامة. وتستهدف المجلة نشر البحوث العلمية الأصيلة والقضايا المعاصرة حول الموضوع، كما ترحب بإسهامات الباحثين أصحاب التخصصات ذات الصلة. وتخضع جميع الأبحاث المقدمة للمجلة للتحكيم من قبل لجنة مختصة. تم اعتماد ستوديا إسلاميكا من قبل وزارة التعليم و الثقافة بجمهورية إندونيسيا باعتبارها دورية علمية (قرار المدير العام للتعليم العالي رقم: 56/DIKTI/Kep/2012).

ستوديا إسلاميكا عضو في CrossRef (الإحالات الثابتة في الأدبيات الأكاديمية) منذ ع ا • ب، و بالتالي سإن جميع المقالات التي نشرها مرقمة حسب معرّف الوثيقة الرقمية (DOI) .

$$
\begin{aligned}
& \text { قيمة الاشتر الك السنوي خارج إندونيسيا: }
\end{aligned}
$$

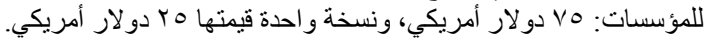

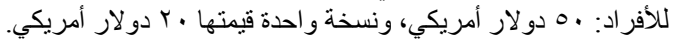

$$
\begin{aligned}
& \text { والقيمة لا تشمل نفقة الإرسال بالبريد الجوي، ونسي. }
\end{aligned}
$$

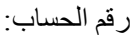

$$
\begin{aligned}
& \text { خارج إندونيسيا (دولار أمريكي): }
\end{aligned}
$$

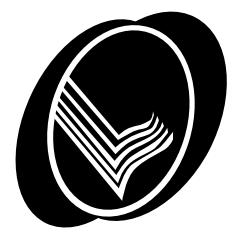




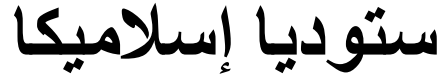 \\ مجلة إندونيسيا للار اسات الإسلامية}

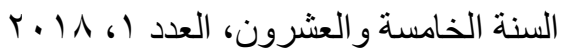

$$
\begin{aligned}
& \text { أزيو ماردي أزرا } \\
& \text { مدير التحرير: } \\
& \text { هيئة التحرير: } \\
& \text { سيف المزاني } \\
& \text { جمهاري } \\
& \text { ديدين شفر الدين }
\end{aligned}
$$

محمد قريش شهاب (جامعة شريف هداية الله الإسلامية الحكومية بجاكرتا)

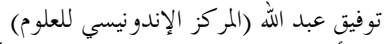

نور أ. فاضل لو بيس (الجامعة الإسلامية الحكومية سومطرة الشمالية الشمالية) م. ش. ريكليف (جامعة أستر اليا الحكومية كانبيرا)

مارتين فان برو نيسين (جامعة أتريخة)

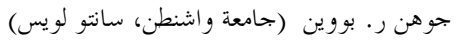

محمد كمال حسن (الجامعة الإسلامية العالمية - ماليزيا)

فر كنيا م. هو كير (جامعة أستراليا الحكومية كانبيرا)

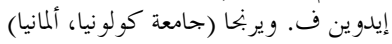

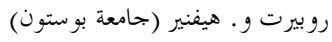

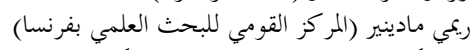

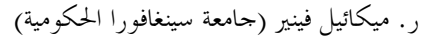

ميكائيل ف. لفان (جامعة فرينشتون)

مساعد هيئة التحرير:

مراجعة اللغة الإنجليزية:

بنيمن ج. فريمان

دانيل فتريون

موسى بتول

مراجعة اللغة العربية:

أحمدي عثمان المبلة

تصميم الغلاف:

س. س برنكا 



\section{لالتوايا السالمسيا}




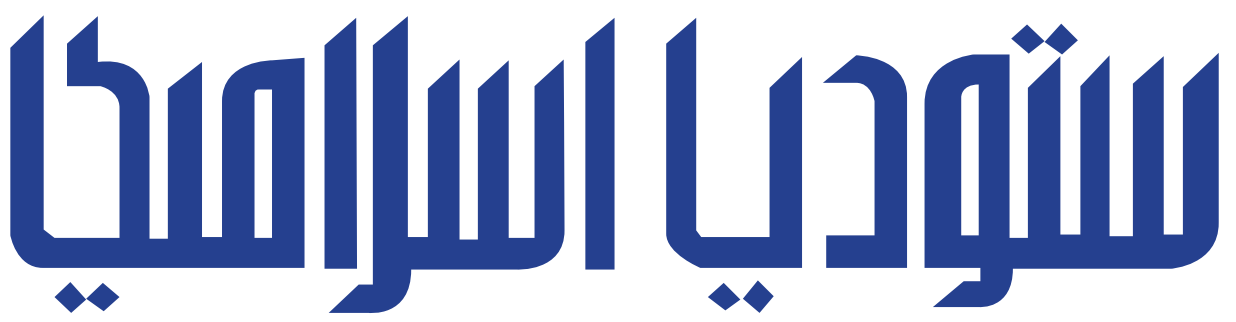

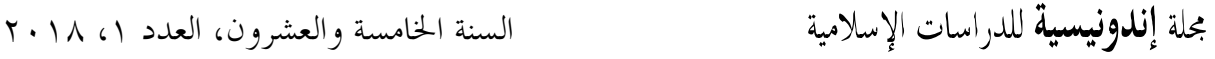

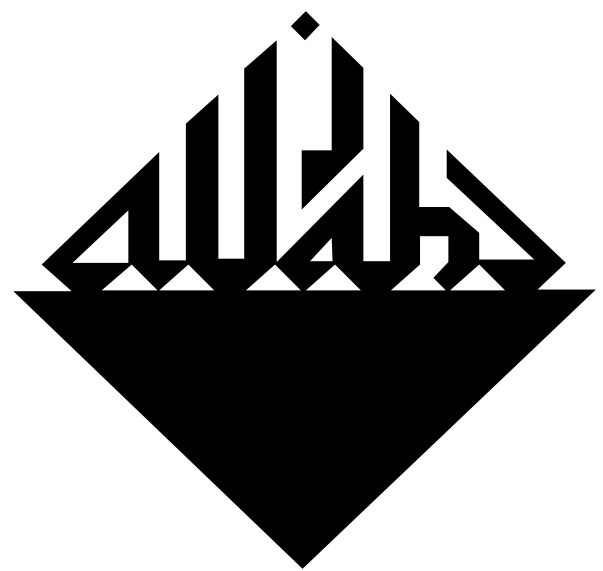

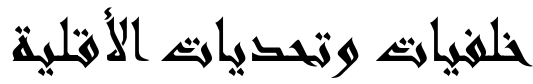

Pontianak المسلمة الصبيمية هيمى هرمانشاه 